\title{
Når hjernen går opp i røyk
}

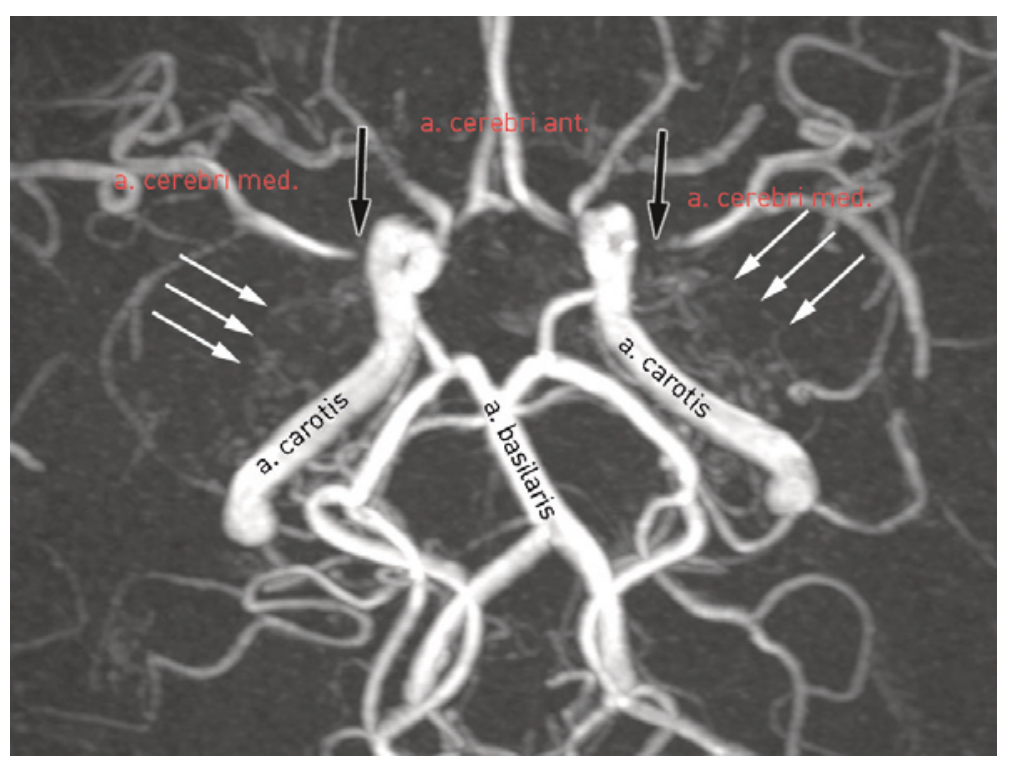

Et barn i skolealder ble innlagt etter en episode med forbigående afasi og hemiparese. Det ble gjort MR av hodet med angiografisekvenser som viste innsnevring av øvre deler av begge arteria carotis interna. På MRbildet så man at stenosen fortsatte videre og omfattet proksimale deler av a. cerebri media (svarte piler). Rundt de trange partiene så man mange, små kollaterale blodkar (hvite piler).

Moyamoya er en sjelden sykdom i hjernens blodkar og innebærer en progressiv stenosering av toppen av a. carotis interna og de avgående arteriene fra Willis' arterielle sirkel (1). Det oppstår en kompensatorisk utvikling av kollaterale kar. For å stille diagnosen vil man videre utføre en cerebral røntgenangiografi. Man vil da enda tydeligere se at dette karnettverket har et karakteristisk utseende som ofte sammenliknes med en «sky av røyk», som oversatt til japansk er «moyamoya». Tidligere har man trodd at sykdommen kun rammet personer av asiatisk opphav, men den er også blitt påvist på andre kontinenter. Årsaken er ukjent, men genetiske faktorer spiller trolig en viktig rolle. De vanligste symptomene som fører til diagnosen er episoder med nevrologiske utfall grunnet iskemi (transitoriske iskemiske anfall eller hjerneinfarkt), kramper, hodepine eller hjerneblødning. Ubehandlet har sykdommen en alvorlig prognose med høy risiko for gjentatte cerebrovaskulære hendelser (1).

Behandlingen består av kirurgisk revaskularisering av området distalt for det trange partiet, og i dette tilfellet ble det utført en anastomose mellom a. temporalis superficialis og a. cerebri media på begge sider. Barnet har i dag, vel tre år etter operasjonen, ingen sekveler og slo hjul på kontoret ved forrige kontroll.

Pasienten og de pårørende har gitt samtykke til at artikkelen blir publisert.

\section{Vidar Rao}

vidarrao@gmail.com

Institutt for nevromedisin

Norges teknisk-naturvitenskapelige universitet og

Nevrokirurgisk avdeling

St. Olavs hospital

\section{Kjell Arne Kvistad}

Institutt for sirkulasjon og bildediagnostikk

Norges teknisk-naturvitenskapelige universitet og

Klinikk for bildediagnostikk

St. Olavs hospital

\section{Sasha Gulati}

Institutt for nevromedisin

Norges teknisk-naturvitenskapelige universitet og

Nevrokirurgisk avdeling

St. Olavs hospital
Vidar Rao (f. 1982) er ph.d., førsteamanuensis og lege i spesialisering i nevrokirurgi. Forfatter har fylt ut ICMJE-skjemaet og oppgir ingen interessekonflikter.

Kjell Arne Kvistad (f. 1960) er dr.med., spesialist i radiologi, førsteamanuensis og overlege. Forfatter har fylt ut ICMJE-skjemaet og oppgir ingen interessekonflikter.

Sasha Gulati (f. 1981) er ph.d., spesialist i nevrokirurgi, forsker og overlege.

Forfatter har fylt ut ICMJE-skjemaet og oppgir ingen interessekonflikter.

Litteratur

1. Scott RM, Smith ER. Moyamoya disease and moyamoya syndrome. N Engl J Med 2009; 360: $1226-37$.

Mottatt 12.9. 2013, første revisjon innsendt 11.11 . 2013, godkjent 3.12. 2013. Redaktør: Matilde Risopatron Berg. 